\title{
Nitrite as a causal factor for nitrate-dependent anaerobic corrosion of metallic iron induced by Prolixibacter strains
}

\author{
Takao Iino $^{1}$, Nobuaki Shono ${ }^{1}$, Kimio Ito ${ }^{2}$, Ryuhei Nakamura ${ }^{1}$, Kazuo Sueoka ${ }^{2}$, Shigeaki \\ Harayama $^{3}$, and Moriya Ohkuma ${ }^{1}$ \\ ${ }^{1}$ RIKEN \\ ${ }^{2}$ Nippon Steel and Sumitomo Metal Corp \\ ${ }^{3}$ Chuo University
}

June 21, 2021

\begin{abstract}
Microbially influenced corrosion (MIC) may contribute significantly to overall corrosion risks, especially in the gas and petroleum industries. In this study, we isolated four Prolixibacter strains, which belong to the phylum Bacteroidetes, and examined their nitrate-respiration- and Fe0-corroding activities, together with two previously isolated Prolixibacter strains. Four of the six Prolixibacter strains reduced nitrate under anaerobic conditions, while the other two strains did not. The anaerobic growth of the four nitrate-reducing strains was enhanced by nitrate, which was not observed in the two nitrate-non-reducing strains. When the nitrate-reducing strains were grown anaerobically in the presence of $\mathrm{Fe} 0$ or carbon steel, the corrosion of the materials was enhanced by more than 20-fold compared to that in aseptic controls. This enhancement was not observed in cultures of the nitrate-non-reducing strains. The oxidation of $\mathrm{Fe} 0$ in the anaerobic cultures of nitrate-reducing strains occurred concomitantly with the reduction of nitrite. Since nitrite chemically oxidized Fe0 under anaerobic and aseptic conditions, the corrosion of Fe0and carbon-steel by the nitrate-reducing Prolixibacter strains was deduced to be mainly enhanced via the biological reduction of nitrate to nitrite, followed by the chemical oxidation of $\mathrm{Fe} 0$ to $\mathrm{Fe} 2+$ and $\mathrm{Fe} 3+$ coupled to the reduction of nitrite.
\end{abstract}

\section{INTRODUCTION}

It has long been recognized that certain microorganisms accelerate the corrosion of carbon- and stainless steel. This phenomenon is referred to as microbially influenced corrosion (MIC) (Javaherdashti, 2008). Under aerobic conditions, microorganisms can promote or inhibit the corrosion of metallic iron $\left(\mathrm{Fe}^{0}\right)$ through oxygen respiration (Zarasvand and Rai, 2014). A specific group of sulfate-reducing bacteria (SRB) accelerates $\mathrm{Fe}^{0}$ corrosion in anaerobic environments (Enning and Garrelfs, 2014), with recent evidence indicating that the direct electron transfer from $\mathrm{Fe}^{0}$ to $\mathrm{SRB}$ via extracellular electron transfer is mediated by outer-membrane cytochromes (Beese-Vasbender et al. , 2015; Deng et al. , 2018; Dinh et al. , 2004; Venzlaff et al. , 2013). Some hydrogenotrophic methanogens that reduce carbon dioxide to methane $\left(\mathrm{CO}_{2}\right.$ respiration) have been found to be capable of causing $\mathrm{MIC}$ on $\mathrm{Fe}^{0}$ (Daniels et al. , 1987; Moriet al. , 2010; Uchiyama et al. , 2010) by secreting specific $[\mathrm{NiFe}]$ hydrogenase, thereby catalyzing the oxidation of $\mathrm{Fe}^{0}$ to ferrous ion: $\mathrm{Fe}^{0}+2 \mathrm{H}^{+}$ - $\mathrm{Fe}^{2+}+\mathrm{H}_{2}$ (Tsurumaru et al. , 2018). In addition to SRB and methanogens, three facultatively anaerobic nitrate-reducing bacteria (NRB), namelyParacoccus denitrificans, Bacillus licheniformis, andPseudomonas aeruginosa, have been found to enhance the corrosion of carbon steel in the presence of nitrate (Ginner et al. , 2004; Jia et al. , 2017; Till et al. , 1998; Xu et al. , 2013). Shewanella oneidensis MR-1, notable for its diverse respiratory capabilities also stimulated $\mathrm{Fe}^{0}$ corrosion via nitrate respiration (De Windt et al. , 2003; Miller IIet al. , 2018).

We previously isolated a bacterium that corroded $\mathrm{Fe}^{0}$ concomitantly with the reduction of nitrate to nitrite 
under anaerobic conditions (Iino et al. , 2015a). This strain was classified asProlixibacter denitrificans sp. nov., and is the first $\mathrm{Fe}^{0}$-corroding NRB belonging to the phylumBacteroidetes (Iino et al. , 2015a). However, only two strains, P. bellariivorans strain $\mathrm{F} 2^{\mathrm{T}}$ (Holmeset al. , 2007) and P. denitrificansMIC1$1^{\mathrm{T}}$ (Iino et al. , 2015a), have been isolated thus far. To explore the potential environmental functions and diversity of Prolixibacter strains, we were interested in isolating more Prolixibacter strains, and characterizing their ability to corrode $\mathrm{Fe}^{0}$ under anoxic conditions. In this study, four strains belonging to the genus Prolixibacterwere newly isolated, and their $\mathrm{Fe}^{0}$-corroding activities were examined. We found that some but not all theProlixibacter strains enhanced the corrosion of $\mathrm{Fe}^{0}$. The basis for the phenotypic differentiation between the Prolixibacter strains was also investigated.

\section{MATERIALS AND METHODS}

\subsection{Bacterial strains and culture conditions}

Artificial seawater (Sw) medium was composed of $\left(\mathrm{l}^{-1}\right)$ : $0.15 \mathrm{~g} \mathrm{NH}_{4} \mathrm{Cl}, 0.2 \mathrm{~g} \mathrm{KH}_{2} \mathrm{PO}_{4}, 0.5 \mathrm{~g} \mathrm{KCl}, 18.0 \mathrm{~g} \mathrm{NaCl}$, $2.6 \mathrm{~g} \mathrm{MgCl} 2 \cdot 6 \mathrm{H}_{2} \mathrm{O}, 0.15 \mathrm{~g} \mathrm{CaCl} 2 \cdot 2 \mathrm{H}_{2} \mathrm{O}, 2.5 \mathrm{~g} \mathrm{NaHCO}, 1 \%$ (vol/vol) of filter-sterilized vitamin solution, as described by Wolin et al. (1963), and $1.0 \mathrm{ml}$ of a trace element solution, as used by Touzel and Albagnac (1983), lacking $\mathrm{NaCl}$ and supplemented with $4.0 \mathrm{mg} / 1$ of $\mathrm{Na}_{2} \mathrm{SeO}_{3} \cdot 5 \mathrm{H}_{2} \mathrm{O}$. SPYSw medium was prepared by adding $10 \mathrm{mM}$ sodium sulfate, $10 \mathrm{mM}$ sodium pyruvate, and $0.01 \%$ (wt/vol) yeast extract (Bacto Yeast Extract, Becton Dickinson) to Sw medium. YPSw medium was prepared by adding $0.2 \%$ (wt/vol) yeast extract and $0.2 \%$ (wt/vol) Polypepton (Nihon Pharmaceutical) to Sw medium. NYPSw medium was prepared by adding $10 \mathrm{mM}$ sodium nitrate to YPSw medium. YSw medium was prepared by adding $0.1 \%$ (wt/vol) yeast extract to $\mathrm{Sw}$ medium.

The medium was dispensed by $20 \mathrm{ml}$ into each $50-\mathrm{ml}$ serum bottle. Dissolved air in SPYSw, NYPSw, and YSw media was removed by flushing with $\mathrm{N}_{2}: \mathrm{CO}_{2}(4: 1$ [vol/vol]), and dissolved air in YPSw media was removed by flushing with $\mathrm{H}_{2}: \mathrm{CO}_{2}$ (4:1) at an approximate pressure of $0.15 \mathrm{MPa}$. The bottles were sealed with butyl rubber stoppers. The $\mathrm{pH}$ of the medium was adjusted to 7.0 with $10 \mathrm{mM} \mathrm{NaHCO}$.

P. bellariivorans $\mathrm{F}^{\mathrm{T}}$ (Holmes et al. , 2007) was obtained with JCM accession number of JCM $13498^{\mathrm{T}}$ from the Japan Collection of Microorganisms of the RIKEN Bioresource Center (RIKEN-BRC JCM).

\subsection{Specimens for bacterial isolation}

Crude oil emulsion samples were collected from an oil-production well in Akita Prefecture and two crude oil storage tanks, one in Kagoshima Prefecture and the other in Miyagi Prefecture, Japan. A corrosion-scale sample was collected from the inner surface of a cast-iron pipe for brine transportation at a natural-gas- and iodine-production plant in Chiba Prefecture, Japan. Each of these samples was kept in a transparent oxygenbarrier plastic bag containing an AnaeroPack-Anaero sachet (Mitsubishi Gas Chemical) until inoculation in fresh media.

\subsection{Enrichment, isolation, and cultivation of bacterial strains from crude oil and corrosion-scale samples}

Half a milliliter of each crude oil sample or $1.0 \mathrm{~g}$ of the corrosion-scale sample was added to $20 \mathrm{ml}$ of SPYSw and YPSw media, and cultivated at $25^{\circ} \mathrm{C}$ for 3 weeks. Each of the resultant cultures was diluted 40 -fold in the same medium, and cultivated again for 3 weeks. This procedure was repeated several times. Finally, each of the enriched cultures was streaked on $1.5 \%(\mathrm{w} / \mathrm{v})$ agar slants of the same medium, and cultivated anaerobically for 7 days to isolate a single colony.

\subsection{Growth characterization}

For the growth tests of each bacterial isolate, a preculture was prepared by growing an isolate in NYPSw medium described above at $25^{\circ} \mathrm{C}$ for 30 days. Then, $0.1 \mathrm{ml}$ of the preculture was used to inoculate in $10 \mathrm{ml}$ of $\mathrm{Sw}$ medium supplemented with various organic acids at $10 \mathrm{mM}$. The culture was then grown at $25^{\circ} \mathrm{C}$ for 30 days either aerobically or anaerobically. The resulting growth was determined by measuring at an optical density at $660 \mathrm{~nm}$. 


\subsection{Microscopy}

Routine microscopic observations were performed using an Optiphot microscope (Nikon) and an S4E stereomicroscope (Leica). The morphology of the bacterial cells was observed using a SEM (JSM-6340F; JEOL). For scanning electron microscopy, cells were fixed in $0.1 \mathrm{M}$ cacodylate buffer ( $\mathrm{pH} 7.4$ ) containing $4 \%$ (wt/vol) paraformaldehyde and $4 \%$ (wt/vol) glutaraldehyde at $4^{\circ} \mathrm{C}$ for $2 \mathrm{~h}$, washed with $0.1 \mathrm{M}$ cacodylate buffer $(\mathrm{pH}$ 7.4) once, fixed again in $0.1 \mathrm{M}$ cacodylate buffer ( $\mathrm{pH} 7.4$ ) containing $2 \%$ (wt/vol) glutaraldehyde at $4^{\circ} \mathrm{C}$ for overnight, washed again in $0.1 \mathrm{M}$ cacodylate buffer (pH7.4), and fixed once again in $1 \%$ (wt/vol) tannic acid in $0.1 \mathrm{M}$ cacodylate buffer $(\mathrm{pH} 7.4)$ at $4^{\circ} \mathrm{C}$ for $2 \mathrm{~h}$. Fixed cells were washed four times in $0.1 \mathrm{M}$ cacodylate buffer (pH7.4), and post-fixed with $2 \%$ (wt/vol) osmium tetroxide in $0.1 \mathrm{M}$ cacodylate buffer (pH 7.4) at $4^{\circ} \mathrm{C}$ for $3 \mathrm{~h}$. Samples were dehydrated in an ethanol series $[50 \%, 70 \%, 90 \%$, and $98 \%$ (vol/vol)] each for 30 min, transferred into $t$-butyl alcohol, freeze-dried under a vacuum, and coated with a thin layer of osmium by using an osmium plasma coater (NL-OPC80NS; Nippon Laser and Electron Laboratory). The SEM was also used to observe the surfaces and cross-sections of corroded $\mathrm{Fe}^{0}$ foils.

\subsection{Preparation of DNA, PCR amplification of 16S rRNA genes, and Sanger sequencing}

For the phylogenetic analyses of bacterial isolates, genomic DNA was extracted from the cells of the isolates and purified by the method of Saito and Miura (1963). PCR amplification of 16S rRNA genes with primers $27 \mathrm{~F}$ and $1492 \mathrm{R}$, and sequencing of the PCR products were performed as described previously (Iino et al. , 2015a).

\subsection{Phylogenetic analyses}

In accordance with a previously described method (Iino et al. , 2010), the 16S RNA gene sequences of 12 phylogenetically-related bacteria in the order Bacteroidales were selected. Phylogenetic trees were constructed using the NJ method with CLUSTAL_X (Saitou and Nei, 1987; Thompson et al. , 1997).

\subsection{Accession numbers}

P. denitrificans AT004 and KGS048, and Prolixibacter sp. NT017 and SD074 were deposited in the RIKENBRC JCM under the culture collection accession numbers JCM 18695, JCM 32015, JCM 32016, and JCM 32017, respectively. The 16S rRNA gene sequences of P. denitrificans AT004, KGS048, NT017, and SD074 were deposited in the DDBJ/EMBL/GenBank nucleotide sequence database under accession numbers LC507161, LC507162, LC507163, and LC507164, respectively.

\section{$2.9 \mathrm{Fe}^{0}$-corrosion test}

The $\mathrm{Fe}^{0}$-corrosion activities of Prolixibacterstrains were tested in corrosion-test medium consisting of $\mathrm{Sw}$ medium supplemented with $100 \mathrm{mM}$ HEPES buffer ( $\mathrm{pH} 7.0$ ), $10 \mathrm{mM}$ nitrate, and $0.05 \%$ (wt/vol) yeast extract. Twenty milliliters of this medium was added anaerobically to a $50-\mathrm{ml}$ serum bottle containing a foil of $\mathrm{Fe}^{0}$ (purity > 99.99\%, $10 \times 10 \times 0.1 \mathrm{~mm}$; Sigma-Aldrich), SS400 carbon steel $(10 \times 10 \times 2 \mathrm{~mm}$; Nippon Steel Stainless Corp.), or SUS316L stainless steel $(10 \times 10 \times 2 \mathrm{~mm}$; Nippon Steel Corp.). Air was removed from the medium by flushing with $\mathrm{N}_{2}: \mathrm{CO}_{2}(4: 1)$, and the bottle was sealed with a butyl rubber stopper (Nichiden-Rika Glass). Subsequently, $0.2 \mathrm{ml}$ of a bacterial preculture was added to the medium, and the culture was incubated at $25^{\circ} \mathrm{C}$ for 30 days.

\subsection{Chemical analyses}

The concentrations of oxidized iron, nitrate, nitrite and ammonium ions were determined as previously described (Iino et al. , 2015a). After cultivation, culture fluids $(100 \mu \mathrm{l})$ containing oxidized iron were acidified with $50 \mu \mathrm{l}$ of $6 \mathrm{~N} \mathrm{HCl}$, and reduced with $100 \mu \mathrm{l}$ of $1 \mathrm{M}$ ascorbic acid for the quantification of total iron (ferrous and ferric ions). The iron ion concentration in each of the acidified solutions was determined colorimetrically using $o$-phenanthroline, as described by Sandell (1959). For the quantification of nitrate, nitrite, and ammonium ions, the culture fluids were centrifuged at $20,400 \times g$ for $10 \mathrm{~min}$. The supernatant was recovered, and filtered through a $0.2-\mu \mathrm{m}$ pore membrane filter. Nitrate, nitrite, and ammonium ions in 
the culture were quantified using a high-performance liquid chromatography (HPLC) system (model HIC20Asuper; Shimadzu Corp.) equipped with a conductivity detector (model CDD-10ADsp), a Shim-Pack cation column (IC-C4), and a Shim-Pack anion column (IC-SA2). Corrosion products on the surface of iron coupons were also analyzed using an XRD analyzer with CuKa radiation ranging from $2 \vartheta=5$ to $100^{\circ}$ at a scanning rate of $1^{\mathrm{O}} / \mathrm{min}$ (Rint1500; Rigaku).

\subsection{Measurement of corrosion potential and corrosion current of an $\mathrm{Fe}^{0}$ electrode}

Electrochemical analyses were conducted at $25^{\circ} \mathrm{C}$ in an electrochemical cell ( $8 \mathrm{ml}$ in capacity) equipped with three electrodes, as described by Okamoto et al. (2014), with slight modifications. The working electrode was an $\mathrm{Fe}^{0}$ foil with a surface area of $3.14 \mathrm{~cm}^{2}$, which was placed on the bottom of the electrochemical cell, while the counter and reference electrodes were a platinum wire and an $\mathrm{Ag} / \mathrm{AgCl} /$ (saturated $\mathrm{KCl}$ ) electrode, respectively. Filter-sterilized corrosion-test medium was used as an electrolyte into which a cell suspension was injected to a final optical density at $660 \mathrm{~nm}$ of 0.02 to start the measurement. The corrosion potential of the working electrode was measured continuously, except that, every $8 \mathrm{~h}$, the corrosion potential of the working electrode was swept at $\pm 25 \mathrm{mV}$ versus the corrosion potential for the measurement of the corrosion current of the working electrode.

\section{RESULTS}

\subsection{Characterization of Prolixibacter strains isolated from crude-oil- and corrosion-scale samp- les}

Previously, P. denitrificans MIC1-1 ${ }^{\mathrm{T}}$ was isolated from a crude-oil-emulsion sample collected from an oil well in Akita Prefecture, Japan (Iino et al., 2015a; Ino et al. , 2015b). In this study, a similar method was used to isolate pure bacterial cultures from three crude-oil-emulsion samples and one corrosion-scale sample collected from four different locations (Table S1). Bacteria capable of growing anaerobically in two different media, SPYSw and YPSw, were screened by repeated "dilution and growth" cycles as described in the Materials and Methods. A total of 76 pure cultures were obtained, which were characterized by $16 \mathrm{~S}$ rRNA gene sequencing. As shown in Table S1, 16 Prolixibacter strains whose 16S rRNA gene sequences showed $>95 \%$ identity to that of $P$. denitrificans MIC1- $1^{\mathrm{T}}$ were isolated using SPYSw medium, while only one Prolixibacter strain was obtained when YPSw medium was used for the screening. In the latter medium, bacteria belonging to the genera Aeromonas, Arcobacter, Marinilabilia, and Thiomicrospira were the predominant bacteria.

Only one Prolixibacter culture from a single source was used for further studies. Three pure cultures derived from three different crude oil samples were designated strains AT004, KGS048, and SD074, while one pure culture obtained from a corrosion-scale sample was designated strain NT017 (Table 1). Phylogenetic analysis based on 16S rRNA gene sequences showed that all four isolates formed a cluster with $P$. denitrificans MIC1$1^{\mathrm{T}}$ and $P$. bellariivorans $\mathrm{JCM} 13498^{\mathrm{T}}$ (original strain name is $\mathrm{F} 2^{\mathrm{T}}$ ) in the neighbor-joining $(\mathrm{NJ}$ ) tree, which was supported by a bootstrap value of $100 \%$. Thus, all the isolates were accommodated in the genus Prolixibacter, order Marinilabiliales, and phylum Bacteroidetes (Fig. 1) . Among the four isolates, strains AT004, KGS048, and NT017 were closely related to P. denitrificans MIC1-1 ${ }^{\mathrm{T}}$, with $98.4-99.2 \%$ identity in their $16 \mathrm{~S}$ rRNA gene sequences, whereas strain SD074 was phylogenetically distinct from P. bellariivorans JCM $13498^{\mathrm{T}}$ and $P$. denitrificans $\mathrm{MIC1}-1^{\mathrm{T}}$, with pairwise sequence identities of $97.3 \%$ and $95.6 \%$, respectively (Table S2).

The cells of all the isolates were mainly rods with a width of approximately $0.3-0.5 \mu \mathrm{m}$ and a length of approximately $1.2-6.5 \mu \mathrm{m}$ and had rough cell surfaces (Fig. S1). Spherical cells with a size of $0.6-0.8 \mu \mathrm{m}$ and long rod cells with a length of $15 \mu \mathrm{m}$ or more were observed sometimes. Cells usually occurred singly or in pairs. Motility and spore formation were not observed during phase-contrast microscopy. The cell pellets of strains AT004 and KGS048 collected using centrifugation were salmon pink, while those of strains NT017 and SD074 were beige. The cells of strains AT004, KGS048, NT017, and SD074 were stained Gram-negatively by conventional Gram staining (Table S2).

All Prolixibacter strains grew anaerobically, with the same growth yields, in $\mathrm{Sw}$ medium supplemented with $0.1 \%$ (wt/vol) yeast extract (YSw medium) and $\mathrm{YSw}$ medium devoid of $\mathrm{NH}_{4} \mathrm{Cl}$ (ammonium-free $\mathrm{YSw}$ 
medium) (Fig. 2). Ammonium was formed upon the growth of these strains in ammonium-free YSm medium (Table 2), indicating that this compound was generated by the catabolism of amino acids and other nitrogencontaining compounds present in yeast extract. Thus, yeast extract served as sources of carbon, energy, and nitrogen for the growth of the Prolixibacter strains in ammonium-free YSw medium. The anaerobic growth of P. denitrificans MIC1-1 ${ }^{\mathrm{T}}$ and three newly isolated strains (AT004, KGS048, and SD074) was enhanced in the presence of nitrate (Fig. 2) showing that nitrate respiration improved the growth yield of these strains. On the other hand, neither growth stimulation by nitrate nor the reduction of nitrate was observed in strain NT017 and P. bellariivorans JCM $13498^{\mathrm{T}}$ (Fig. 2 and Table 2), indicating that these two strains did not respire nitrate. The ammonium concentrations in the nitrate-amended cultures of the nitrate-reducing strains were significantly higher than those in the nitrate-free cultures of the nitrate-reducing strains $(\mathrm{P}<0.05$, Student's t-test), while such trends were not observed in the nitrate-non-reducing strains (Table 2). Thus, it seems that the nitrate-reducing strains reduced nitrate not only to nitrite, but also to ammonium. The sum of the nitrite and ammonium concentrations formed during the cultivation of the nitrate-reducing strains were always smaller than the concentrations of nitrate metabolized by these strains. This stoichiometric anomaly could be interpreted as either that ammonium was assimilated by hosts, or that nitrate was also converted to other products than nitrite and ammonium,e.g. nitric oxide.

Yeast extract in YSm medium could be replaced by D-glucose, but not by simple organic acids, including lactate, pyruvate, and acetate (Table S2).

Based on the phylogenetic positions shown in Fig. 1, the phenotypic properties shown in Table S2, and the nitrate-reducing activities described above, strains AT004 and KGS048 are considered to belong to $P$. denitrificans. Strain NT017, whose $16 \mathrm{~S}$ rRNA gene sequence was $98.9 \%$ identical to that of $P$. denitrificans MIC1- ${ }^{\mathrm{T}}$, differed from $P$. denitrificans by its cell color and the absence of nitrate respiration. Strain SD074 was considered to be a new species because of the low identity of its 16S rRNA gene sequence compared with those of $P$. bellariivorans and $P$. denitrificans .

\subsection{Corrosion of $\mathrm{Fe}^{\mathrm{0}}$ by Prolixibacterstrains}

When $P$. denitrificans MIC1- ${ }^{\mathrm{T}}$ and three newly isolated strains $(P$. denitrificans AT004, $P$. denitrificansKGS048, and Prolixibacter sp. SD074) were grown in corrosion-test medium containing $\mathrm{Fe}^{0}$ foils, the surface of the $\mathrm{Fe}^{0}$ foils lost its shine, and turned grayish black within one month of their cultivation. In addition, the color of the medium changed to light yellow, suggestive of the formation of ferric ions in the cultures. On the other hand, these color changes were not observed in the anaerobic cultures of Prolixibacter sp. NT017 or P. bellariivorans JCM $13498^{\mathrm{T}}$. Thus, all nitrate reducers were expected to be $\mathrm{Fe}^{0}$-corroding, while all nitrate non-reducers were not.

To investigate further, $\mathrm{Fe}^{0}$ foils incubated in corrosion-test medium for 30 days in the presence or absence of variousProlixibacter strains were observed with a scanning electron microscope (SEM). As shown in Fig. $3 \mathrm{~A}-\mathrm{B}$ and $3 \mathrm{D}-\mathrm{E}$, cubic crystals developed on the surface of $\mathrm{Fe}^{0}$ foils after incubation with $P$. denitrificans MIC1-1 ${ }^{\mathrm{T}}$ and P. denitrificans AT004. Rod-shaped cells of length 1.5-6 $\mu \mathrm{m}$ were also observed on the surface of $\mathrm{Fe}^{0}$ foils (Fig. 3B and 3E). The cross-sections of $\mathrm{Fe}^{0}$ foils showed that the surface was eroded after incubation with these strains (Fig. 3C and 3F) compared with the aseptic control (Fig. 4I). On the surfaces of $\mathrm{Fe}^{0}$ foils submerged in the cultures of $P$. denitrificans KGS048 and Prolixibacter sp. SD074, amorphous flakes developed (Fig. 3G-L), and the cross-sectional morphology of the corrosion products showed a greater thickness of the corrosion films (Fig. 3I and 3L) than those produced by $P$. denitrificansMIC1- $1^{\mathrm{T}}$ and AT004 (Fig. 3C and 3F). On the other hand, the amounts of corrosion deposits on the surface of the $\mathrm{Fe}^{0}$ foils submerged in the cultures of nitrate non-reducers, namely Prolixibacter sp. NT017 and P. bellariivorans JCM $13498^{\mathrm{T}}$, were minimal (Fig. 4A-F), as well as similar to those in the aseptic control (Fig. 4G-I).

The X-ray diffraction analyses of the corroded $\mathrm{Fe}^{0}$ samples revealed that deposits developed on the surface of $\mathrm{Fe}^{0}$ foils from the cultures of P. denitrificans(MIC1-1 ${ }^{\mathrm{T}}$, AT004, and KGS048) and Prolixibactersp. SD074 mainly consisted of $\mathrm{FeCO}_{3}$ and $\mathrm{Fe}_{3}\left(\mathrm{PO}_{4}\right)_{2}$ (Table S3). In one of the two samples from the cultures of P. denitrificansKGS048 and Prolixibacter sp. SD074, $\mathrm{Fe}_{3} \mathrm{O}_{4} \mathrm{Fe}_{2} \mathrm{O}_{3}$ and $\mathrm{FeO}(\mathrm{OH})$ were also detected on the 
surface of $\mathrm{Fe}^{0}$ foils. A very thin layer of $\mathrm{Fe}_{3}\left(\mathrm{PO}_{4}\right)_{2}$ was detected on the surface of $\mathrm{Fe}^{0}$ foils in the cultures of $P$. bellariivorans $\mathrm{JCM} 13498^{\mathrm{T}}$ and the aseptic control, while corrosion products were not detected on the surface of the $\mathrm{Fe}^{0}$ foils in the culture of Prolixibactersp. NT017. Thus, the electron microscopic studies confirmed the conclusions obtained by visual observation, that is, that the four nitrate-reducing strains $P$. denitrificansMIC1-1 ${ }^{\mathrm{T}}$, P. denitrificans AT004, P. denitrificans KGS048, and Prolixibacter sp. SD074 were $\mathrm{Fe}^{0}$-corrosive, while the two nitrate-non-reducing strains, P. bellariivorans JCM $13498^{\mathrm{T}}$, andProlixibacter sp. NT017, were not.

Changes in the corrosion potential of $\mathrm{Fe}^{0}$ (= working electrode) immersed in corrosion-test medium in the presence or absence of a Prolixibacter strain were examined, as shown in Fig. 5A. In the presence of $\mathrm{Fe}^{0}$ corroding $P$. denitrificansMIC1- ${ }^{\mathrm{T}}$, the corrosion potential shifted in the positive direction from $-680 \mathrm{mV}$ (vs. $\mathrm{KCl}$ saturated $\mathrm{Ag} / \mathrm{AgCl}$ ) to $-600 \mathrm{mV}$ in the first 10 days, followed by a shift in the negative direction. Such intensive changes in the corrosion potential were not observed in the aseptic control or in the presence of $\mathrm{Fe}^{0}$-non-corroding Prolixibacter sp. NT017. Every $8 \mathrm{~h}$ during the continuous measurement of the corrosion potential of the working electrode, the corrosion current was also estimated by sweeping $\pm 25 \mathrm{mV}$ around the corrosion potential. As shown in Fig. 5B, the current density increased between days 2 and 4 from almost zero to $3.2 \mu \mathrm{A} \mathrm{cm}^{-1}$. After day 4 , the current density remained almost unchanged, except between days 10 and 12 , in which it increased temporarily up to approximately $19 \mu \mathrm{A} \mathrm{cm}^{-1}$ (Fig. 5B). On the other hand, no corrosion current $\left(<0.5 \mu \mathrm{A} \mathrm{cm} \mathrm{cm}^{-1}\right)$ was generated upon the polarization of $\mathrm{Fe}^{0}$ in the aseptic control and in the presence of Prolixibacter sp. NT017.

\subsection{Fate of nitrate during $\mathrm{Fe}^{0}$ corrosion}

As has been observed in our previous study (Iino et al. , 2015a),P. denitrificans MIC1- ${ }^{\mathrm{T}}$ grown in corrosiontest medium containing $10 \mathrm{mM}$ nitrate corroded $\mathrm{Fe}^{0}$ to extents more than 20 -fold higher than that in the aseptic control. When yeast extract in corrosion-test medium was substituted by D-glucose, $\mathrm{Fe}^{0}$ oxidation by $P$. denitrificans $\mathrm{MIC} 1-1^{\mathrm{T}}$ was reduced by $50 \%$ probably due to the inhibitory effect of D-glucose on $\mathrm{Fe}^{0}$ corrosion (Isa et al. , 2011). The three newly isolated nitrate-reducing strains, P. denitrificans AT004, P. denitrificans KGS048, and Prolixibacter sp. SD074, also oxidized $\mathrm{Fe}^{0}$ extensively (Table 3). Conversely, the two nitrate-non-reducing strains, Prolixibacter sp. NT017 and P. bellariivorans JCM $13498^{\mathrm{T}}$ did not show such an activity confirming the results from the electron-microscopic and electrochemical studies. None of the six strains enhanced $\mathrm{Fe}^{0}$ corrosion in the presence of sulfate in place of nitrate (Table 3).

In $\mathrm{Fe}^{0}$-foil-containing corrosion-test media inoculated with the nitrate-reducing strains, nitrate was reduced by $50 \%$ over 30 days (Table 3) similarly to the results in Table 2. On the other hand, the nitrite concentrations were lower, while the ammonium concentrations were higher in the $\mathrm{Fe}^{0}$-containing cultures (Table 3) compared to $\mathrm{Fe}^{0}$-free cultures (Table 2). From these results, and from the previous finding that nitrite chemically corrodes $\mathrm{Fe}^{0}$ (Alowitz and Scherer, 2002), we hypothesized that $\mathrm{Fe}^{0}$ was chemically oxidized to $\mathrm{Fe}^{2+}$ and/or $\mathrm{Fe}^{3+}$ concomitantly with the reduction of nitrite to ammonium.

To clarify this point, time-course changes in the concentrations of nitrate, nitrite, and ammonium in the cultures of the four nitrate-reducing strains in the presence or absence of $\mathrm{Fe}^{0}$ were examined for four weeks. As shown in Fig. 6, a similar trend was observed among the four strains for the concentration changes of nitrate, nitrite and ammonium. In all the cultures (Fig. 6A-D, and F-I), the nitrate concentrations decreased sharply during the first week, followed by gradual decreases. Unexpectedly, the nitrite concentrations only increased slightly during the first week compared to the sharp decrease in the nitrate concentrations. Thus, the vast majority of nitrate reduced during the first 7 days was assimilated into biomass. This conclusion is in agreement with the results in Fig. 1; namely, the growth of the nitrate-reducing strains reached a plateau at day 7 .

In the $\mathrm{Fe}^{0}$-non-amended cultures (Fig. $6 \mathrm{~A}-\mathrm{D}$ ), the ammonium concentrations decreased during the first 2 to 4 days, indicating that a portion of ammonium present in corrosion-test medium was used as a nitrogen source during the growth of these strains. Subsequently, the ammonium concentrations increased. The nitrite concentrations in the same cultures increased continuously until the end of the cultivation period. 
In the $\mathrm{Fe}^{0}$-amended cultures (Fig. $6 \mathrm{~F}-\mathrm{I}$ ), the changes in the nitrite and ammonium concentrations were different compared with those in the $\mathrm{Fe}^{0}$-non-amended cultures. Compared to the ammonium concentrations in the $\mathrm{Fe}^{0}$-non-amended cultures, those in the $\mathrm{Fe}^{0}$-amended cultures were similar for the first two weeks, but higher in the last two weeks. On the other hand, the nitrite concentrations in the $\mathrm{Fe}^{0}$-amended cultures were highest on day 7 , after which they declined. This decline was interpreted to be due to the chemical reduction of nitrite to ammonium coupled with the chemical oxidation of $\mathrm{Fe}^{0}$. In such a reaction, the reduction of one mole of nitrite to ammonium is coupled to the oxidation of either $2 \mathrm{~mol}$ of $\mathrm{Fe}^{0}$ to $\mathrm{Fe}^{3+}$, or $3 \mathrm{~mol} \mathrm{of} \mathrm{Fe}^{0}$ to $\mathrm{Fe}^{2+}$. To determine whether this stoichiometry was established, the relationship between the formation of oxidized iron and the consumption of nitrite was examined. As shown in Fig. 7, the increment in the

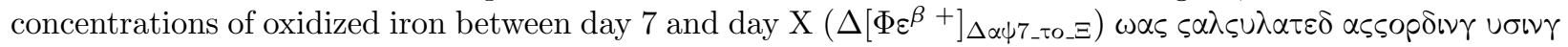

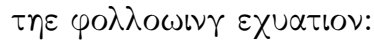

$\Delta\left[\Phi \varepsilon^{\beta+}\right]_{\Delta \alpha \psi 7_{-} \tau_{-} \Xi}=\left[\Phi \varepsilon^{\beta+}\right]_{\Delta \alpha \psi \Xi}-\left[\Phi \varepsilon^{\beta+}\right]_{\Delta \alpha \psi 7}$

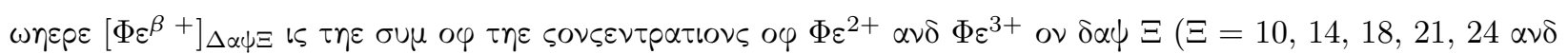

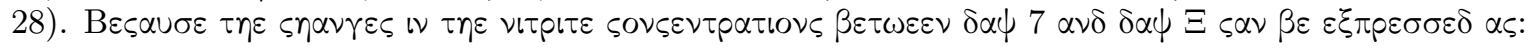

$\left[\mathrm{NO}_{2}^{-}\right]_{\Delta \alpha \psi \Xi}-\left[\mathrm{NO}_{2}^{-}\right]_{\Delta \alpha \psi 7}=\sigma \psi \nu\left[\mathrm{NO}_{2}^{-}\right]_{\Delta \alpha \psi 7_{-} \tau o_{-} \Xi^{-}} \delta \varepsilon \gamma\left[\mathrm{NO}_{2}{ }^{-}\right]_{\Delta \alpha \psi 7_{-} \tau o_{-} \Xi}$

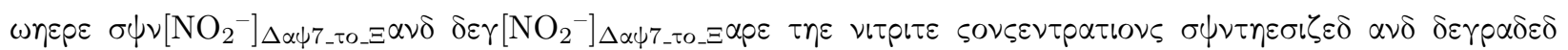

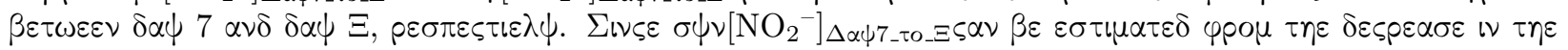

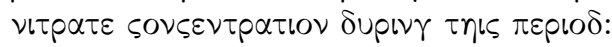

$\sigma \psi \nu\left[\mathrm{NO}_{2}{ }^{-}\right]_{\Delta \alpha \psi 7_{-} \tau o_{-} \Xi}=\left[\mathrm{NO}_{3}{ }^{-}\right]_{\Delta \alpha \psi 7}-\left[\mathrm{NO}_{3}{ }^{-}\right]_{\Delta \alpha \psi \xi}$

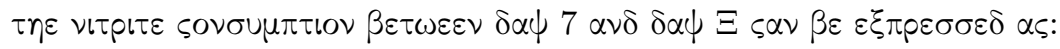

$\delta \varepsilon \gamma\left[\mathrm{NO}_{2}^{-}\right]_{\Delta \alpha \psi 7_{-} \tau_{-} \Xi}=\left[\mathrm{NO}_{3}^{-}\right]_{\Delta \alpha \psi 7^{-}}-\left[\mathrm{NO}_{3}^{-}\right]_{\Delta \alpha \psi \Xi}+\left[\mathrm{NO}_{2}^{-}\right]_{\Delta \alpha \psi 7^{-}}-\left[\mathrm{NO}_{2}^{-}\right]_{\Delta \alpha \psi \Xi}$

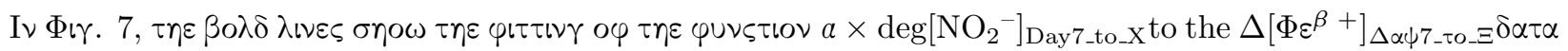

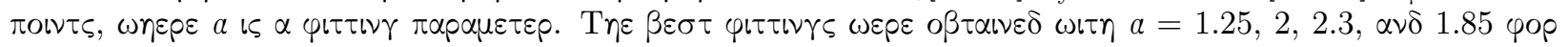

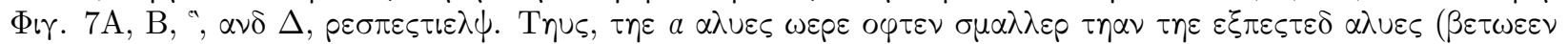

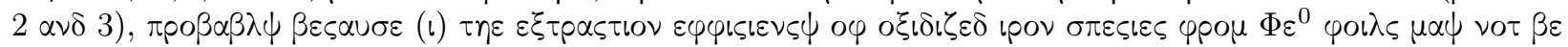

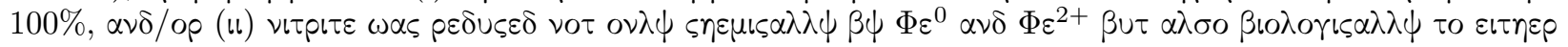

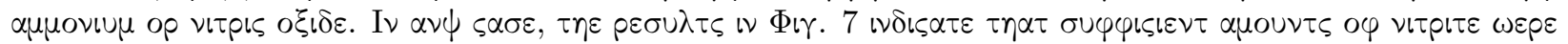

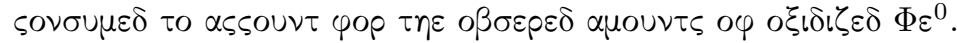

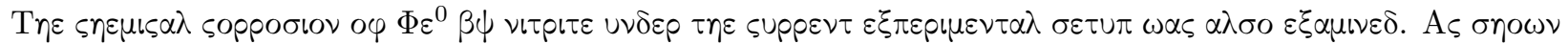

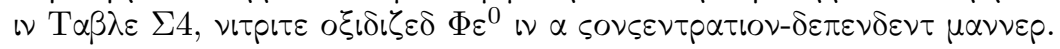

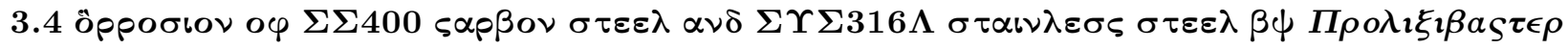

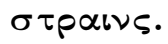

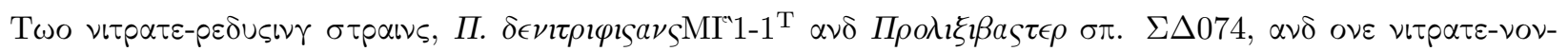

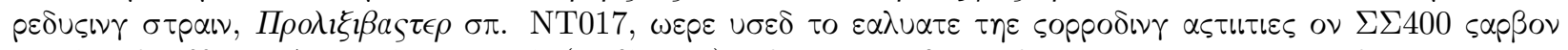

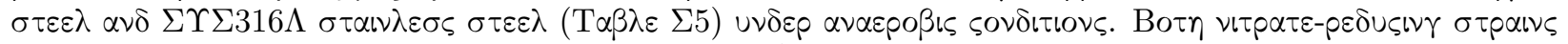

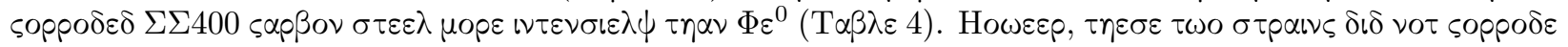

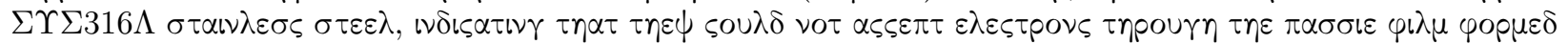

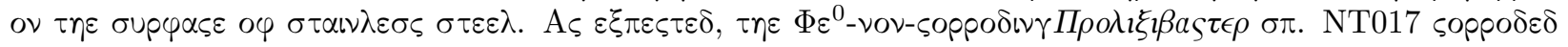

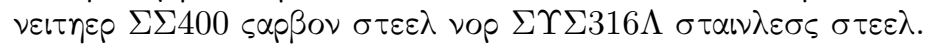

\section{$4 \Delta \mathrm{I} \Sigma \mathrm{\Upsilon} \Upsilon \Sigma \Sigma \mathrm{ION}$}

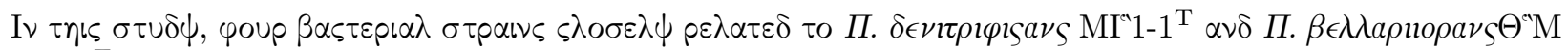

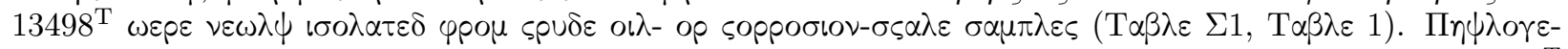

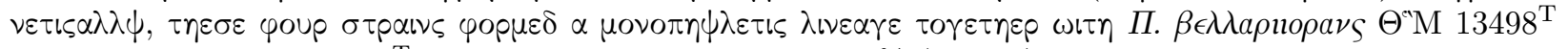

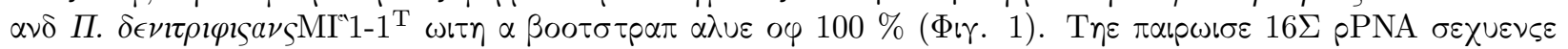

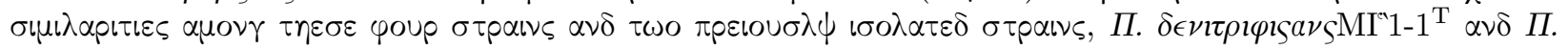




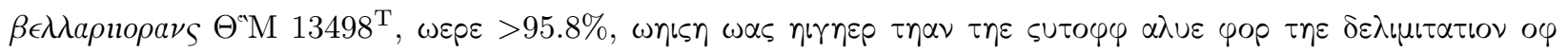

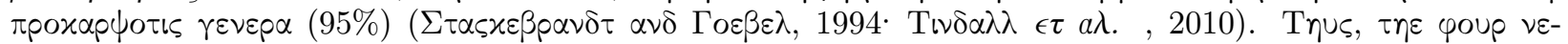

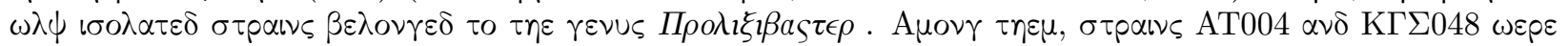

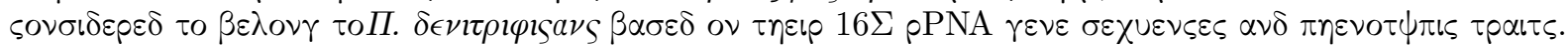

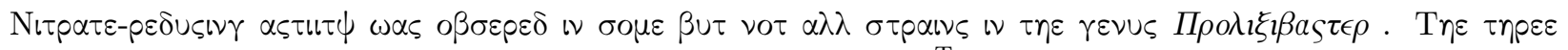

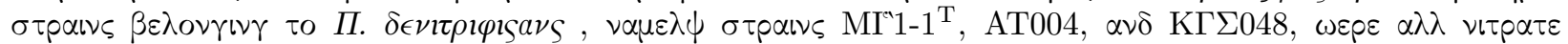

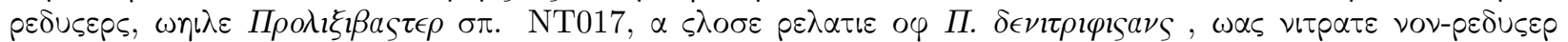

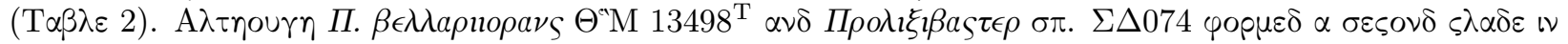

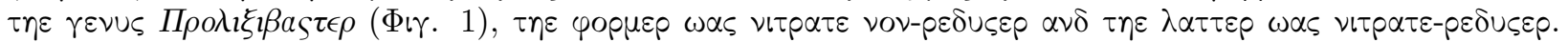

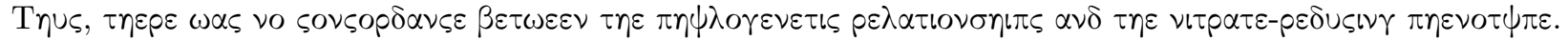

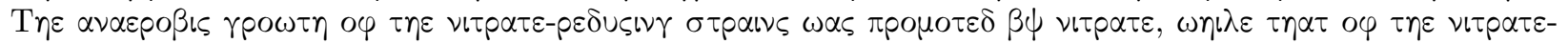

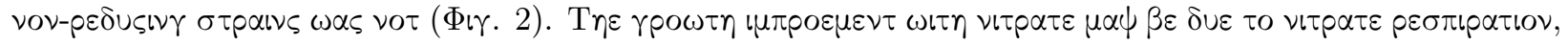

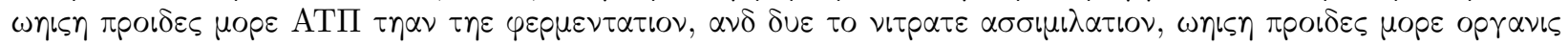

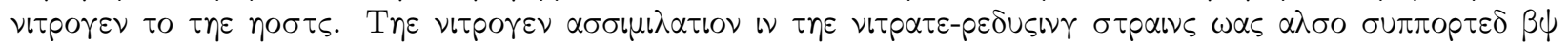

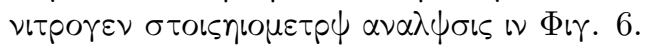

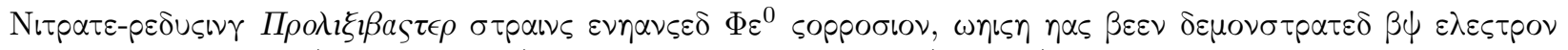

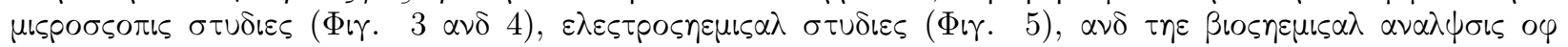

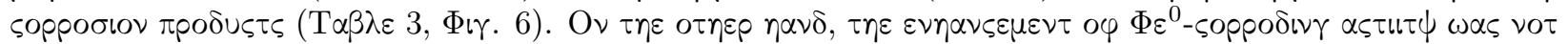

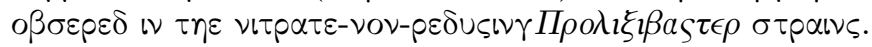

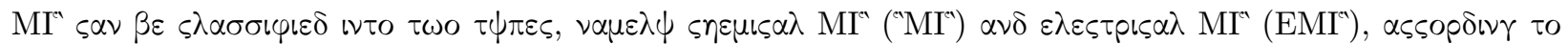

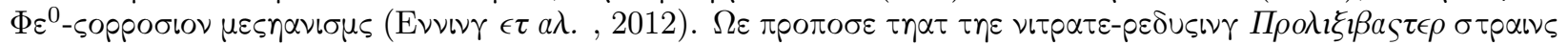

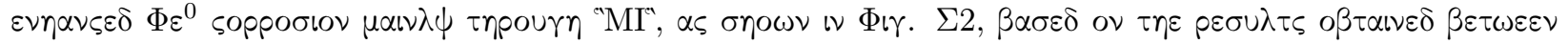

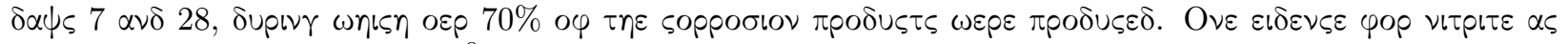

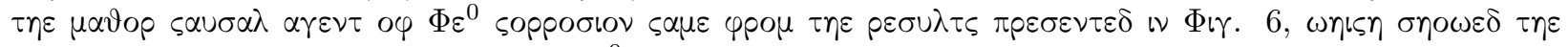

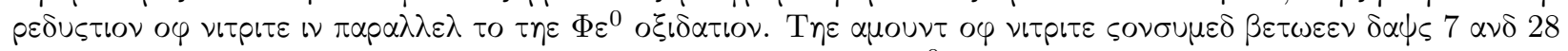

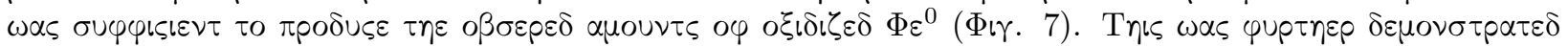

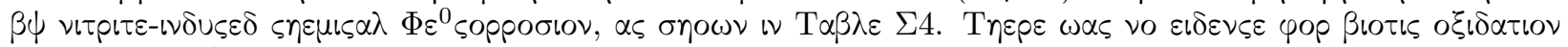

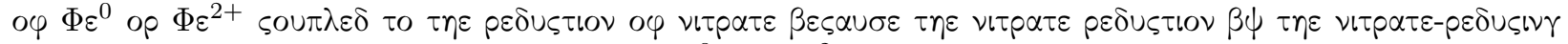

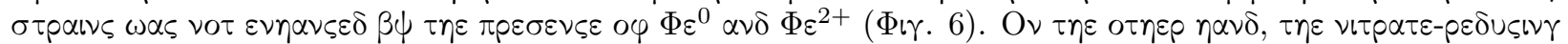

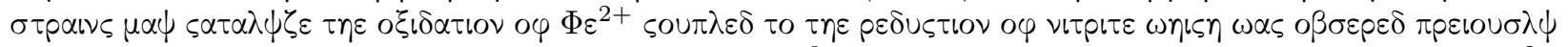

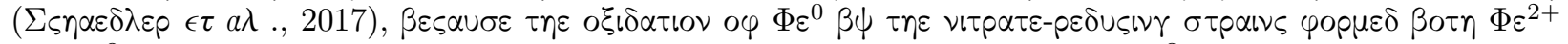

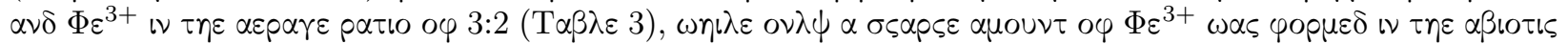

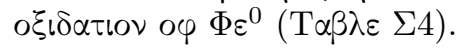

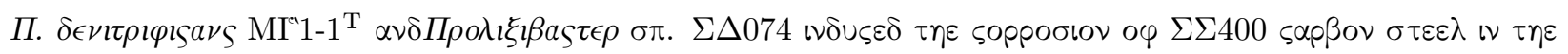

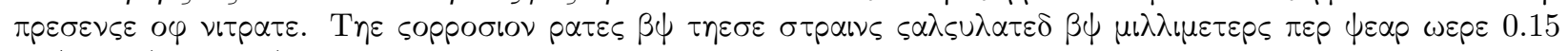

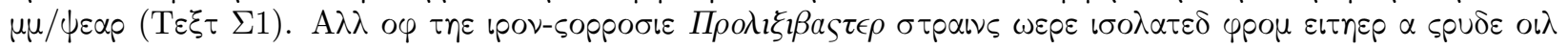

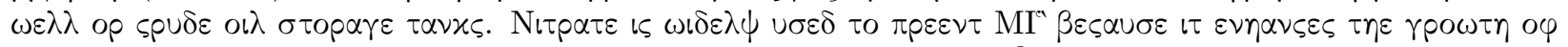

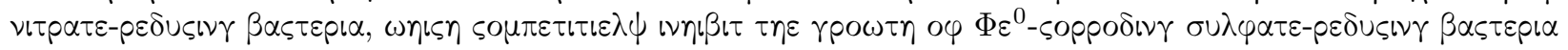

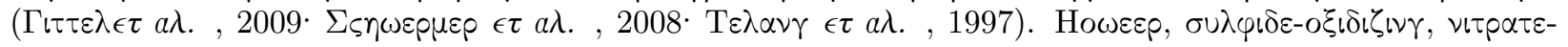

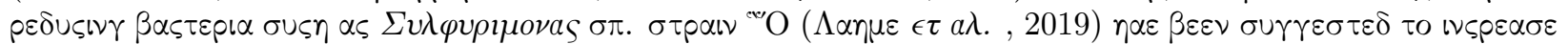

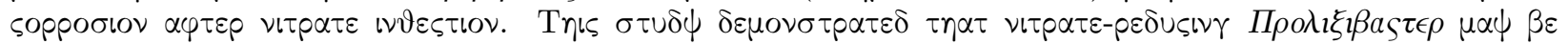

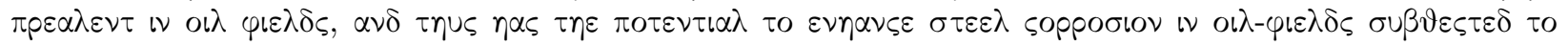

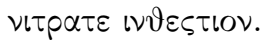

\section{A“KNO $\Omega \Lambda E \Delta \Gamma E M E N T \Sigma$}

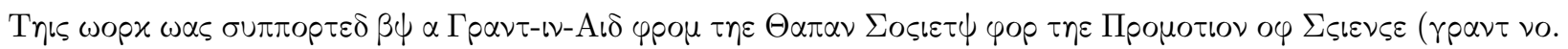

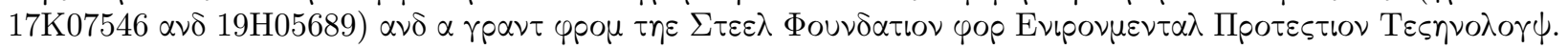

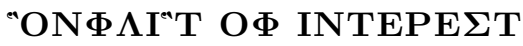


Nove $\delta \varepsilon \varsigma \lambda \alpha p \varepsilon \delta$.

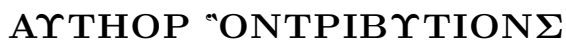

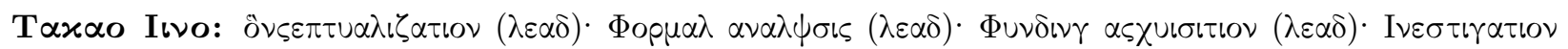

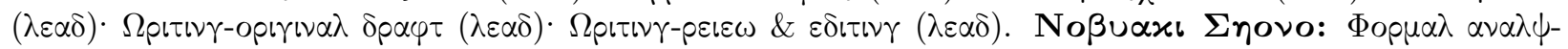

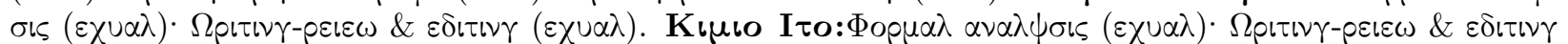

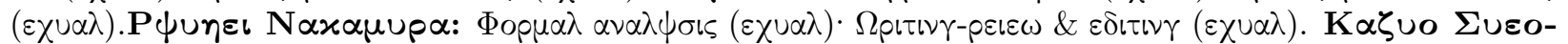

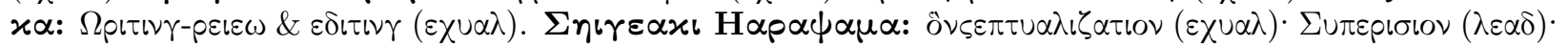

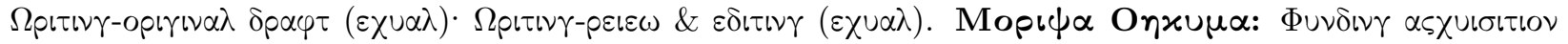

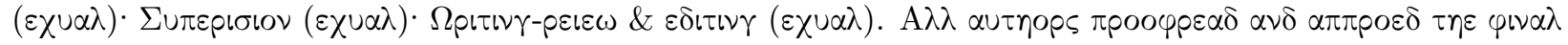
$\varepsilon \rho \sigma เ O \nu O \varphi \tau \eta \varepsilon \mu \alpha \nu \cup \sigma \varsigma \rho l \pi \tau$.

\section{ETHI" $\Sigma$ $\Sigma$ TATEMENT}

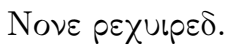

\section{$\triangle$ ATA A*AI}

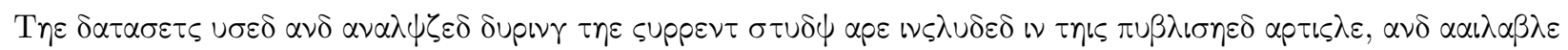

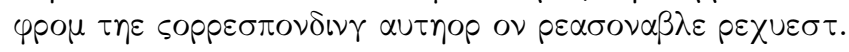

\section{OP"I $\Delta$}

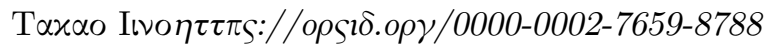

\section{PETEPEN"E $\Sigma$}

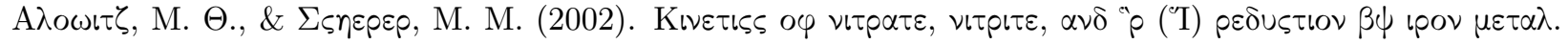

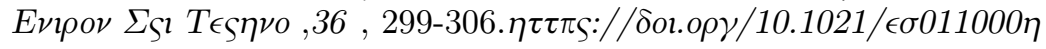

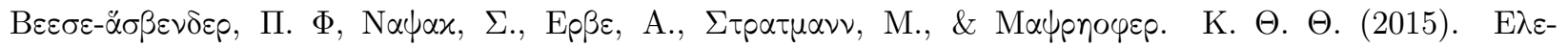

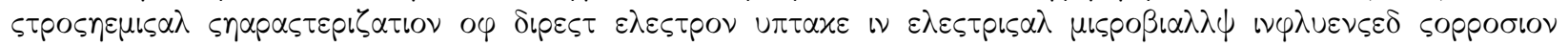

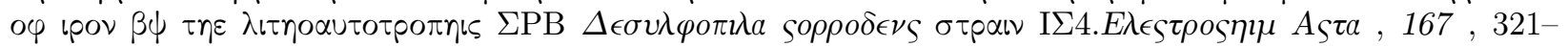
$329 . \eta \tau \tau \pi \varsigma: / / \delta o l . o \rho \gamma / 10.1016 / \vartheta . \epsilon \lambda \epsilon \varsigma \tau \alpha \varsigma \tau a .2015 .03 .184$

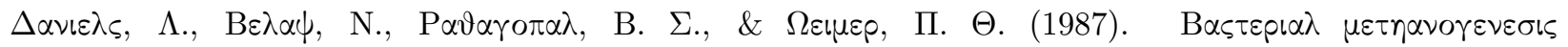

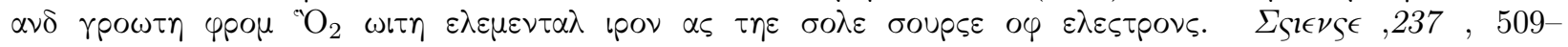
511. $\eta \tau \tau \pi \varsigma: / / \delta o l . o \rho \gamma / 10.1126 / \sigma \varsigma l \epsilon \nu_{\varsigma} \epsilon .237 .4814 .509$

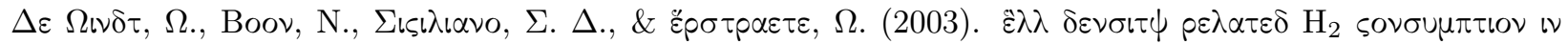

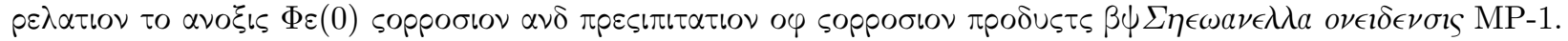

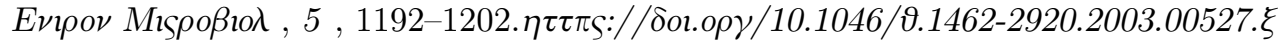

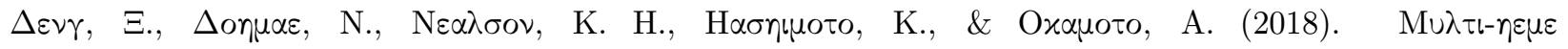

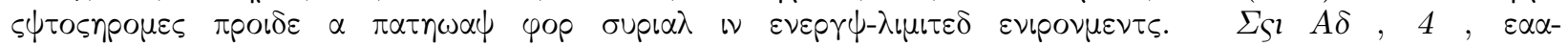

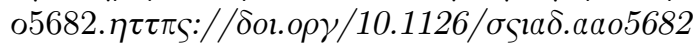

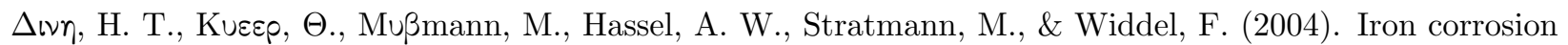
by novel anaerobic microorganisms. Nature , 427 , 829-832.https://doi.org/10.1038/nature02321

Enning, D., \& Garrelfs, J. (2014). Corrosion of iron by sulfate-reducing bacteria: new views of an old problem. Appl Environ Microbiol , 80 , 1226-1236.https://doi.org/10.1128/AEM.02848-13

Enning, D., Venzlaff, H., Garrelfs, J., Dinh, H. T., Meyer, V., Mayrhofer, K., Hassel, A. W., Stratmann, M., \& Widdel, F. (2012). Marine sulfate-reducing bacteria cause serious corrosion of iron under electroconductive biogenic mineral crust. Environ Microbiol ,14 , 1772-1787.https://doi.org/10.1111/j.14622920.2012.02778.x 
Ginner, J. L., Alvarez, P. J. J., Smith, S. L., \& Scherer, M. M. (2004). Nitrate and nitrite reduction by $\mathrm{Fe}^{0}$ : influence of mass transport, temperature, and denitrifying microbes.Environ Eng Sci , 21 , 219229.https://doi.org/10.1089/109287504773087381

Gittel, A., Sørensen, K. B., Skovhus, T. L., Ingvorsen, K., \& Schramm, A. (2009). Prokaryotic community structure and sulfate reducer activity in water from high-temperature oil reservoirs with and without nitrate treatment. Appl Environ Microbiol , 75 , 7086-7096.https://doi.org/10.1128/AEM.01123-09

Holmes, D. E., Nevin, K. P., Woodard, T. L., Peacock, A. D., \& Lovley, D. R. (2007). Prolixibacter bellariivorans gen. nov., sp. nov., a sugar-fermenting psychrotolerant anaerobe of the phylumBacteroidetes, isolated from a marine-sediment fuel cell.Int J Syst Evol Microbiol , 57, 701-707.https://doi.org/10.1099/ijs.0.642960

Iino, T., Sakamoto, M., \& Ohkuma, M. (2015a). Prolixibacter denitrificans sp. nov., an iron-corroding, facultatively aerobic, nitrate-reducing bacterium isolated from crude oil, and emended descriptions of the genus Prolixibacter and Prolixibacter bellariivorans. Int J Syst Evol Microbiol , 65 , 28652869.https://doi.org/10.1099/ijs.0.000343

Iino, T., Ito, K., Wakai, S., Tsurumaru, H., Ohkuma, M., \& Harayama, S. (2015b). Iron corrosion induced by nonhydrogenotrophic nitrate-reducing Prolixibacter sp. strain MIC1-1. Appl Environ Microbiol ,81 , 18391846.https://doi.org/10.1128/AEM.03741-14

Ino, T., Mori, K., Uchino, Y., Nakagawa, T., Harayama, S., \& Suzuki, K. (2010). Ignavibacterium album gen. nov., sp. nov., a moderately thermophilic anaerobic bacterium isolated from microbial mats at a terrestrial hot spring and proposal of Ignavibacteriaclassis nov., for a novel lineage at the periphery of green sulfur bacteria. Int J Syst Evol Microbiol , 60 , 1376-1382.https://doi.org/10.1099/ijs.0.012484-0

Isa, M. I. H., Cheng, Y. L., \& Isa, M. I. N., (2012). Saccharides glucose as a potential corrosion inhibition for mild steel in seawater.Int J Recent Sci Res , 2 , 123-127.

Javaherdashti. R. (2008). Microbiologically influenced corrosion: an engineering insight. Springer-Verlag. New York.

Jia, R., Yang, D., Xu, D., \& Gu, T. (2017). Electron transfer mediators accelerated the microbiologically influence corrosion against carbon steel by nitrate reducing Pseudomonas aeruginosa biofilm.Bioelectrochemistry , 118 , 38-46.https://doi.org/10.1016/j.bioelechem.2017.06.013

Lahme, S., Enning, D., Callbeck, C. M., Vega, D. M., Curtis, T. P., Head, I. M., \& Huberta, C. R. J. (2019). Metabolites of an oil field sulfide-oxidizing, nitrate-reducing Sulfurimonas sp. cause severe corrosion. Appl Environ Microbiol , 85, e01891-18.https://doi.org/10.1128/AEM.01891-18

Miller II, R. B., Lawson, K., Sadek, A., Monty, C. N., \& Senko, J. M. (2018). Uniform and pitting corrosion of carbon steel byShewanella oneidensis MR-1 under nitrate-reducing conditions.Appl Environ Microbiol, 84, e00790-18.https://doi.org/10.1128/AEM.00790-18

Mori, K., Tsurumaru, H., \& Harayama, S. (2010). Iron corrosion activity of anaerobic hydrogen-consuming microorganisms isolated from oil facilities. $J$ Biosci Bioeng , 110 , 426430.https://doi.org/10.1016/j.jbiosc.2010.04.012

Okamoto, A., Kalathil, S., Deng, X., Hashimoto, K., Nakamura, R., \& Nealson, K. H. (2014). Cell-secreted flavins bound to membrane cytochromes dictate electron transfer reactions to surfaces with diverse charge and pH. Sci Rep , 4 , 5628.https://doi.org/10.1038/srep05628

Saito, H., \& Miura, K. (1963). Preparation of transforming deoxyribonucleic acid by phenol treatment. Biochim Biophys Acta ,72 , 619-629.https://doi.org/10.1016/0926-6550(63)90386-4

Saitou, N., \& Nei, M. (1987). A neighbor-joining method: a new method for reconstructing phylogenetic trees. Mol Biol Evol , 4 , 406-425.https://doi.org/10.1093/oxfordjournals.molbev.a040454 
Sandell, E.B. (1959). Colorimetric determination of trace metals. The chemical analysis monograph series, vol. 3. Interscience Publishers, Inc, New York, NY.

Schaedler, F., Lockwood, C., Lueder, U., Glombitza, C., Kappler, A., \& Schmidta, C. (2018). Microbially mediated coupling of $\mathrm{Fe}$ and $\mathrm{N}$ cycles by nitrate-reducing $\mathrm{Fe}(\mathrm{II})$-oxidizing bacteria in littoral freshwater sediments. Appl Environ Microbiol, 84, e02013-17.https://doi.org/10.1128/AEM.02013-17

Schwermer, C. U., Lavik, G., Abed, R. M. M., Dunsmore, B., Ferdelman, T. G., Stoodley, P., Gieseke, A, \& de Beer, D. (2008). Impact of nitrate on the structure and function of bacterial biofilm communities in pipelines used for injection of seawater into oil fields. Appl Environ. Microbiol , 74 , 28412851.https://doi.org/10.1128/AEM.02027-07

Stackebrandt, E., \& Goebel, B. M. (1994). Taxonomic note: a place for DNA-DNA reassociation and 16S rRNA sequence analysis in the present species definition in bacteriology. Int J Syst Evol Microbiol ,44 , 846-849.https://doi.org/10.1099/00207713-44-4-846

Telang, A. J., Evert, S., Foght, J. M., Westlake, D. W. S., Jenneman, G. E., Gevertz, D., \& Voordouw, G. (1997). Effect of nitrate injection on the microbial community in an oil field as monitored by reverse sample genome probing. Appl Environ Microbiol , 63 , 1785-1793.https://doi.org/10.1128/AEM.63.5.17851793.1997

Thompson, J. D., Gibson, T. J., Plewniak, F., Jeanmougin, F., \& Higgins, D. G. (1997). The CLUSTAL_X Windows interface: flexible strategies for multiple sequence alignment aided by quality analysis tool. Nucleic Acids Res , 24 , 4876-4882.https://doi.org/10.1093/nar/25.24.4876

Till, B. A., Weathers, L. J., \& Alvarez, P. J. J. (1998). Fe(0)-supported autotrophic denitrification. Environ Sci Technol , 32, 634-639.https://doi.org/10.1021/es9707769

Tindall, B. J., Rosselló-Móra, R., Busse, H. J., Ludwig, W., \& Kämpfer, P. (2010). Notes on the characterization of prokaryote strains for taxonomic purposes. Int J Syst Evol Microbiol , 60 , 249266.https://doi.org/10.1099/ijs.0.016949-0

Touzel, J. P., \& Albagnac, G. (1983). Isolation and characterization ofMethanococcus mazei strain $\mathrm{MC}_{3}$. FEMS Microbiol Lett , 16 , 241-245.https://doi.org/10.1111/j.1574-6968.1983.tb00295.x

Tsurumaru, H., Ito, N., Mori, K., Wakai, S., Uchiyama, T., Iino, T., Hosoyama, A, Ataku, H, Nishijima, K, Mise, M, Shimizu, A, Harada, T, Horikawa, H, Ichikawa, N, Sekigawa, T, Jinno, K, Tanikawa, S, Yamazaki, J, Sasaki, K, Yamazaki, S, Fujita, N, \& Harayama, S. (2018). An extracellular [NiFe] hydrogenase mediating iron corrosion is encoded in a genetically unstable genomic island in Methanococcus maripaludis. Sci Rep , 8 , 15149.https://doi.org/10.1038/s41598-018-33541-5

Uchiyama, T., Ito, K., Mori, K., Tsurumaru, H., \& Harayama, S. (2010). Iron-corroding methanogen isolated from a crude-oil storage tank.Appl Environ Microbiol , 76 , 1783-1788.https://doi.org/10.1128/AEM.0066809

Venzlaff, H., Enning, D., Srinivasan, J., Mayrhofer, K. J. J., Hassel, A. W., Widdel, F., \& Stratmann, M. (2013). Accelerated cathodic reaction in microbial corrosion of iron due to direct electron uptake by sulfate-reducing bacteria. Corros Sci ,66 ,88-96.https://doi.org/10.1016/j.corsci.2012.09.006

Wolin, E. A., Wolin, M. J., \& Wolfe, R. S. (1963). Formation of methane by bacterial extracts. J Biol Chem , $238,2882-2886$.

Xu, D., Li, Y., Song, F., \& Gu, T. (2013). Laboratory investigation of microbiologically influenced corrosion of C1018 carbon steel by nitrate reducing bacterium Bacillus licheniformi s. Corros Sci ,77, 385390.https://doi.org/10.1016/j.corsci.2013.07.044

Zarasvand, K. A., \& Rai, V. R. (2014). Microorganisms: induction and inhibition of corrosion in metals. Int Biodeterior Biodegradation , 87 , 66-74.https://doi.org/10.1016/j.ibiod.2013.10.023 


\section{Figure legends}

Fig. 1. Phylogenetic tree of four bacterial isolates and representatives of related species based on the $16 \mathrm{~S}$ rRNA gene sequences. The tree was inferred from an alignment of 1,380-bp-long sequences of 16S rRNA genes, and constructed by the neighbor-joining method. The numbers at the nodes denote the bootstrap percentages derived from 1,000 replications. Scale bar: 0.01 substitutions per nucleotide position.

Fig. 2. Anaerobic growth of $P$. denitrificans $\mathrm{MIC} 1-1^{\mathrm{T}}$ (A), P. denitrificans AT004 (B),P. denitrificans KGS048 (C), Prolixibacter sp. SD074 (D).Prolixibacter sp. NT017 (E), and

P. bellariivorans JCM $13498^{\mathrm{T}}(\mathrm{F})$. These strains were grown anaerobically in either YSw medium (open symbol) or ammonium-free YSw medium (closed symbol) in the presence (circle) or absence (triangle) of 10 $\mathrm{mM}$ sodium nitrate. Data represent the means $(n=3)$, with standard deviation values less than $18 \%$ of the corresponding mean values.

Fig. 3. Scanning electron micrographs showing the surface and cross-sections of $\mathrm{Fe}^{0}$ foils incubated anaerobically with nitrate-reducing Prolixibacter strains. $\mathrm{Fe}^{0}$ foils were incubated for 30 days in corrosion-test medium in the presence of $P$. denitrificans MIC1- ${ }^{\mathrm{T}}(\mathrm{A}-\mathrm{C}), P$. denitrificans AT004 (D-F), $P$. denitrificans KG048 (G-I), and Prolixibacter sp. SD074 (J-L). A, D, G, and J: the surface of Fe ${ }^{0}$ foils $(\times 300$ magnification). $\mathrm{B}, \mathrm{E}, \mathrm{H}$, and $\mathrm{K}$ : the surface of $\mathrm{Fe}^{0}$ foils $(\times 1,000$ magnification $) . \mathrm{C}, \mathrm{F}$, I, and $\mathrm{L}$ : the cross-section of $\mathrm{Fe}^{0}$ foils $(\times 300$ magnification). Scale bar: $10 \mu \mathrm{m}$ for A, C, D, F, G, I, J, and L; $1 \mu \mathrm{m}$ for B, E, H, and K. Scanning electron micrographs were obtained from two independent experiments.

Fig. 4. Scanning electron micrographs showing the surface and cross-sections of $\mathrm{Fe}^{0}$ foils incubated anaerobically with nitrate-non-reducing Prolixibacter strains. $\mathrm{Fe}^{0}$ foils were incubated for 30 days in corrosion-test medium in the presence of Prolixibacter sp. NT017 (A-C), and P. belleriivorans JCM $13498^{\mathrm{T}}$ (D-F). The aseptic controls are also shown $(\mathrm{G}-\mathrm{I})$. A, D, and G: the surface of $\mathrm{Fe}^{0}$ foils $(\times 300$ magnification). B, E, and $\mathrm{H}$ : the surface of $\mathrm{Fe}^{0}$ foils $\left(\times 1,000\right.$ magnification). $\mathrm{C}, \mathrm{F}$, and $\mathrm{I}$ : the cross-section of $\mathrm{Fe}^{0}$ foils $(\times 300$ magnification). Bar $=10 \mu \mathrm{m}$ for A, C, D, F, G, and I. Scale bar: $1 \mu \mathrm{m}$ for B, E, and H. Scanning electron micrographs were obtained from two independent experiments.

Fig. 5. Corrosion potential and corrosion current of an $\mathrm{Fe}^{0}$ electrode immersed in the cultures of $P$. denitrificans strain MIC1-1 $1^{\mathrm{T}}$ and Prolixibactersp. NT017. Corrosion potential and corrosion current of an $\mathrm{Fe}^{0}$ electrode were determined as described in the Materials and Methods. (A) Change in the corrosion potential of an $\mathrm{Fe}^{0}$ foil used as the working electrode. (B) Change in the corrosion current generated at the $\mathrm{Fe}^{0}$ foil poised at $25 \mathrm{mV}$ versus corrosion potential. Solid red line: in the presence of $P$. denitrificans MIC1-1 ${ }^{\mathrm{T}}$; dashed green line: in the presence of Prolixibacter sp. strain NT017; dotted black line, aseptic control.

Fig. 6. Nitrate reduction and the accumulation of nitrite and ammonium in the cultures of nitrate-reducing Prolixibacterstrains. Nitrate-reducing Prolixibacter strains were grown under an atmosphere of $\mathrm{N}_{2}: \mathrm{CO}_{2}$ (4:1) in corrosion-test medium either in the presence ( $\mathrm{A}$ to $\mathrm{E}$ ) or absence ( $\mathrm{F}$ to $\mathrm{J}$ ) of an $\mathrm{Fe}^{0}$ foil. In $\mathrm{F}$ to $\mathrm{J}$, the concentrations of oxidized iron in the aseptic controls were between $0 \mathrm{mM}$ at day 0 and $0.2 \mathrm{mM}$ at day 28. The strains used were $P$. denitrificansMIC1-1 ${ }^{\mathrm{T}}$ (A and F), P. denitrificans AT004 (B and G), $P$. denitrificans KGS048 (C and H) Prolixibactersp. SD074 (D and I), and aseptic control (E and J). Filled circle: nitrate concentration, filled triangle: nitrite concentration, cross: ammonium concentration, and open circles: concentration of oxidized iron. Data represent means $(n=3)$, with standard deviation values less than $8.9 \%$ of the corresponding mean values.

Fig. 7. The relationship between $\mathrm{Fe}^{0}$ oxidation and nitrite reduction. The data in Fig. 6 are rearranged to show the relationships between the increment in the concentration of oxidized iron (open circles) and the consumed concentration of nitrite (filled triangle) during three weeks after day 7 . The latter concentration was calculated as described in the text. The strains used were $P$. denitrificans $\mathrm{MIC1}-\mathrm{1}^{\mathrm{T}}$ (A), P. denitrificans AT004 (B), P. denitrificans KGS048 (C), andProlixibacter sp. SD074 (D). Bold lines were obtained by multiplying the values of the consumed concentration of nitrite by $a$ where $\mathrm{a}=1.25$ for $\mathrm{A}, 2$ for $\mathrm{B}, 2.4$ for 
C, and 1.85 for D. Data represent means $(n=3)$, with standard deviation values less than $8.9 \%$ of the corresponding mean values.

Table 1. Bacterial strains used in this study.

Species

Prolixibacter denitrificans

Prolixibacter sp.

Prolixibacter sp.

Prolixibacter bellariivorans

Abbreviations: ATCC, American Type Culture Collection; DSM, German Collection of Microorganisms and Cell Cultures;

Table 2. Nitrate reduction and/or the production of nitrite and/or ammonium during the anaerobic growth of Prolixibacter strains cultured in ammonium-free YSw medium in the presence and absence of nitrate and ammonium.

\begin{tabular}{|c|c|c|c|c|c|c|}
\hline Species & Strain & $\mathrm{NO}_{3}$ & $\mathrm{NH}_{4}$ & Nitrate reduced (mM) & Nitrite formed (mM) & Ammonium for \\
\hline \multirow[t]{4}{*}{ Prolixibacter denitrificans } & $\mathrm{MIC}_{1-1^{\mathrm{T}}}$ & - & - & N.A. & N.A. & $1.1 \pm 0.11$ \\
\hline & & - & + & N.A. & N.A. & $1.0 \pm 0.27$ \\
\hline & & + & - & $5.1 \pm 0.94$ & $1.8 \pm 0.65$ & $1.4 \pm 0.41$ \\
\hline & & + & + & $4.8 \pm 0.97$ & $3.3 \pm 1.14$ & $1.4 \pm 0.19$ \\
\hline \multirow[t]{4}{*}{ Prolixibacter denitrificans } & AT004 & - & - & N.A. & N.A. & $0.5 \pm 0.07$ \\
\hline & & - & + & N.A. & N.A. & $0.5 \pm 0.03$ \\
\hline & & + & - & $5.2 \pm 0.07$ & $2.5 \pm 0.07$ & $1.0 \pm 0.39$ \\
\hline & & + & + & $5.0 \pm 0.07$ & $2.6 \pm 0.07$ & $1.1 \pm 0.14$ \\
\hline \multirow[t]{4}{*}{ Prolixibacter denitrificans } & KGS048 & - & - & N.A. & N.A. & $0.6 \pm 0.11$ \\
\hline & & - & + & N.A. & N.A. & $0.6 \pm 0.08$ \\
\hline & & + & - & $4.8 \pm 0.07$ & $1.7 \pm 0.07$ & $0.9 \pm 0.27$ \\
\hline & & + & + & $5.0 \pm 0.07$ & $3.2 \pm 0.07$ & $1.0 \pm 0.35$ \\
\hline \multirow[t]{4}{*}{ Prolixibacter sp. } & SD074 & - & - & N.A. & N.A. & $0.3 \pm 0.05$ \\
\hline & & - & + & N.A. & N.A. & $1.0 \pm 0.58$ \\
\hline & & + & - & $5.6 \pm 1.19$ & $2.0 \pm 0.67$ & $1.2 \pm 0.16$ \\
\hline & & + & + & $6.8 \pm 0.65$ & $4.4 \pm 0.50$ & $1.6 \pm 0.05$ \\
\hline \multirow[t]{4}{*}{ Prolixibacter sp. } & NT017 & - & - & N.A. & N.A. & $0.8 \pm 0.08$ \\
\hline & & - & + & N.A. & N.A. & $0.8 \pm 0.04$ \\
\hline & & + & - & $0.4 \pm 0.29$ & $<0.01$ & $0.4 \pm 0.08$ \\
\hline & & + & + & $0.3 \pm 0.16$ & $<0.01$ & $0.6 \pm 0.16$ \\
\hline \multirow[t]{4}{*}{ Prolixibacter bellariivorans } & JCM $13498^{\mathrm{T}}$ & - & - & N.A. & N.A. & $0.6 \pm 0.06$ \\
\hline & & - & + & N.A. & N.A. & $0.6 \pm 0.07$ \\
\hline & & + & - & $0.4 \pm 0.29$ & $<0.01$ & $0.4 \pm 0.14$ \\
\hline & & + & + & $0.2 \pm 0.25$ & $<0.01$ & $0.6 \pm 0.12$ \\
\hline
\end{tabular}

Each of the six Prolixibacter strains was grown anaerobically at $25^{\circ} \mathrm{C}$ for 30 days under an atmosphere of $\mathrm{N}_{2}: \mathrm{CO}_{2}$ (4:1) in a 50-ml serum bottle containing $20 \mathrm{ml}$ of ammonium-free YSw medium or the medium supplemented with $10 \mathrm{mM}$ nitrate and/or $2.8 \mathrm{mM}$ ammonium. The concentrations of nitrate, nitrite, and ammonium in each culture or in an aseptic control at day 30 were determined, and those in the aseptic control were subtracted from the respective values in each culture. Data represent means and standard deviations 
$(n=3)$.

N.A.: not applicable.

Table $3 . \mathrm{Fe}^{0}$ corrosion and nitrate reduction to nitrite and ammonium in the cultures of Prolixibacter strains.

\begin{tabular}{|c|c|c|c|c|c|c|c|c|}
\hline Species & Strain & $\begin{array}{l}\text { Electron } \\
\text { acceptor }\end{array}$ & $\begin{array}{l}\text { Carbon } \\
\text { source }\end{array}$ & $\begin{array}{l}\text { Oxidized } \\
\text { iron }(\mathrm{mM})\end{array}$ & $\begin{array}{l}\text { Oxidized } \\
\text { iron }(\mathrm{mM})\end{array}$ & $\begin{array}{l}\text { Oxidized } \\
\text { iron }(\mathrm{mM})\end{array}$ & $\begin{array}{l}\text { Nitrate } \\
\text { reduced } \\
(\mathrm{mM})\end{array}$ & $\begin{array}{l}\text { Nitrite } \\
\text { formed } \\
(\mathrm{mM})\end{array}$ \\
\hline & & & & $\begin{array}{l}\text { Total } \\
\text { iron } \\
(\mathrm{mM})\end{array}$ & $\begin{array}{l}\mathrm{Fe}^{2+} \\
(\mathrm{mM})\end{array}$ & $\begin{array}{l}\mathrm{Fe}^{3+} \\
(\mathrm{mM})\end{array}$ & & \\
\hline \multirow{4}{*}{$\begin{array}{l}\text { Prolixibacter } \\
\text { denitri- } \\
\text { ficans }\end{array}$} & & Nitrate & Glucose & $2.9 \pm$ & $2.8 \pm$ & $0.1 \pm$ & $3.3 \pm$ & $0.1 \pm$ \\
\hline & $1^{\mathrm{T}}$ & & & 0.01 & 0.02 & 0.02 & 1.3 & 0.01 \\
\hline & & Nitrate & $\begin{array}{l}\text { Yeast } \\
\text { ex. }\end{array}$ & $\begin{array}{l}4.7 \pm \\
0.5\end{array}$ & $\begin{array}{l}2.2 \pm \\
0.2\end{array}$ & $\begin{array}{l}2.1 \pm \\
0.5\end{array}$ & $\begin{array}{l}5.1 \pm \\
0.3\end{array}$ & $\begin{array}{l}0.4 \pm \\
0.07\end{array}$ \\
\hline & & Sulfate & $\begin{array}{l}\text { Yeast } \\
\text { ex. }\end{array}$ & $\begin{array}{l}0.1 \pm \\
0.02\end{array}$ & - & - & - & - \\
\hline \multirow{2}{*}{\multicolumn{2}{|c|}{$\begin{array}{l}\text { Prolixibacter AT004 } \\
\text { denitri- } \\
\text { ficans }\end{array}$}} & Nitrate & $\begin{array}{l}\text { Yeast } \\
\text { ex. }\end{array}$ & $\begin{array}{l}4.3 \pm \\
0.3\end{array}$ & $\begin{array}{l}3.0 \pm \\
0.1\end{array}$ & $1.5 \pm 0$ & $\begin{array}{l}5.3 \pm \\
0.3\end{array}$ & $\begin{array}{l}0.3 \pm \\
0.04\end{array}$ \\
\hline & & Sulfate & $\begin{array}{l}\text { Yeast } \\
\text { ex. }\end{array}$ & $\begin{array}{l}0.5 \pm \\
0.09\end{array}$ & - & - & - & - \\
\hline \multirow{2}{*}{\multicolumn{2}{|c|}{$\begin{array}{l}\text { Prolixibacter KGS048 } \\
\text { denitri- } \\
\text { ficans }\end{array}$}} & Nitrate & $\begin{array}{l}\text { Yeast } \\
\text { ex. }\end{array}$ & $\begin{array}{l}4.8 \pm \\
0.4\end{array}$ & $\begin{array}{l}2.8 \pm \\
0.5\end{array}$ & $\begin{array}{l}1.3 \pm \\
0.2\end{array}$ & $\begin{array}{l}5.4 \pm \\
0.4\end{array}$ & $\begin{array}{l}0.3 \pm \\
0.08\end{array}$ \\
\hline & & Sulfate & $\begin{array}{l}\text { Yeast } \\
\text { ex. }\end{array}$ & $\begin{array}{l}0.2 \pm \\
0.11\end{array}$ & - & - & - & - \\
\hline \multirow{2}{*}{\multicolumn{2}{|c|}{$\begin{array}{l}\text { Prolixibacter SD074 } \\
\text { sp. }\end{array}$}} & Nitrate & $\begin{array}{l}\text { Yeast } \\
\text { ex. }\end{array}$ & $\begin{array}{l}5.4 \pm \\
0.5\end{array}$ & $\begin{array}{l}2.8 \pm \\
0.4\end{array}$ & $\begin{array}{l}2.4 \pm \\
0.4\end{array}$ & $\begin{array}{l}4.9 \pm \\
0.2\end{array}$ & $\begin{array}{l}0.6 \pm \\
0.04\end{array}$ \\
\hline & & Sulfate & $\begin{array}{l}\text { Yeast } \\
\text { ex. }\end{array}$ & $\begin{array}{l}0.3 \pm \\
0.01\end{array}$ & - & - & - & - \\
\hline \multirow{2}{*}{\multicolumn{2}{|c|}{$\begin{array}{l}\text { Prolixibacter NT017 } \\
\text { sp. }\end{array}$}} & Nitrate & $\begin{array}{l}\text { Yeast } \\
\text { ex. }\end{array}$ & $\begin{array}{l}0.2 \pm \\
0.03\end{array}$ & $\begin{array}{l}0.2 \pm \\
0.01\end{array}$ & $\begin{array}{l}0 \pm \\
0.01\end{array}$ & $\begin{array}{l}0 \pm \\
0.13\end{array}$ & $<0.01$ \\
\hline & & Sulfate & $\begin{array}{l}\text { Yeast } \\
\text { ex. }\end{array}$ & $\begin{array}{l}0.3 \pm \\
0.07\end{array}$ & - & - & - & - \\
\hline \multirow{2}{*}{\multicolumn{2}{|c|}{$\begin{array}{ll}\text { Prolixibacter } & \mathrm{JCM} \\
\text { bellari- } & 13498^{\mathrm{T}} \\
\text { ivorans } & \end{array}$}} & Nitrate & $\begin{array}{l}\text { Yeast } \\
\text { ex. }\end{array}$ & $\begin{array}{l}0.2 \pm \\
0.10\end{array}$ & $\begin{array}{l}0.2 \pm \\
0.01\end{array}$ & $\begin{array}{l}0 \pm \\
0.01\end{array}$ & $\begin{array}{l}0 \pm \\
0.13\end{array}$ & $<0.01$ \\
\hline & & Sulfate & $\begin{array}{l}\text { Yeast } \\
\text { ex. }\end{array}$ & $\begin{array}{l}0.2 \pm \\
0.20\end{array}$ & - & - & - & - \\
\hline
\end{tabular}

Each of the six Prolixibacter strains was grown anaerobically at $25^{\circ} \mathrm{C}$ for 30 days under an atmosphere of $\mathrm{N}_{2}: \mathrm{CO}_{2}$ (4:1) in a 50-ml serum bottle containing an $\mathrm{Fe}^{0}$ foil immersed in $20 \mathrm{ml}$ of corrosion-test medium or the medium containing $10 \mathrm{mM}$ sulfate in place of nitrate. The concentrations of oxidized iron, nitrate, nitrite, and ammonium in each culture at day 30 were determined, and those in the aseptic control were subtracted from the respective values in each culture. Data represent means and standard deviations $(n=$ 3). -: Not determined.

Table 4. Corrosion activities of two $\mathrm{Fe}^{0}$-corroding Prolixibacter strains on $\mathrm{Fe}^{0}$, carbon steel, and stainless steel. 


\begin{tabular}{|c|c|c|c|}
\hline Species & Strain & Metal type & Oxidized iron $(\mathrm{mM})$ \\
\hline \multirow[t]{3}{*}{ Prolixibacter denitrificans } & MIC1-1 ${ }^{\mathrm{T}}$ & $\mathrm{Fe}^{0}$ & $4.2 \pm 0.2$ \\
\hline & & SS400 & $9.0 \pm 0.4$ \\
\hline & & SUS316L & $0.1 \pm 0.002$ \\
\hline \multirow[t]{3}{*}{ Prolixibacter sp. } & SD074 & $\mathrm{Fe}^{0}$ & $5.1 \pm 0.4$ \\
\hline & & SS400 & $6.7 \pm 0.2$ \\
\hline & & SUS316L & $0.1 \pm 0.002$ \\
\hline \multirow[t]{3}{*}{ Prolixibacter sp. } & NT017 & $\mathrm{Fe}^{0}$ & $0.2 \pm 0.03$ \\
\hline & & SS400 & $0 \pm 0.002$ \\
\hline & & SUS316L & $0 \pm 0.002$ \\
\hline \multirow[t]{3}{*}{ Aseptic control } & & $\mathrm{Fe}^{0}$ & $0.2 \pm 0.12$ \\
\hline & & SS400 & $0 \pm 0.002$ \\
\hline & & SUS316L & $0 \pm 0.002$ \\
\hline
\end{tabular}

P. denitrificans $\mathrm{MIC} 1-1^{\mathrm{T}}$ andProlixibacter sp. SD074 grew anaerobically at $25^{\circ} \mathrm{C}$ for 30 days under an atmosphere of $\mathrm{N}_{2}: \mathrm{CO}_{2}(4: 1)$ in a 50-ml serum bottle containing either an $\mathrm{Fe}^{0}$ foil, a coupon of SS400 carbon steel, or a coupon of SUS316L stainless steel immersed in $20 \mathrm{ml}$ of corrosion-test medium. The concentrations of oxidized iron in each culture at day 30 were determined. Data represent means and standard deviations $(n=3)$.

\section{Hosted file}

Fig.1-7.pdf available at https://authorea.com/users/420843/articles/527114-nitrite-as-acausal-factor-for-nitrate-dependent-anaerobic-corrosion-of-metallic-iron-induced-byprolixibacter-strains 